\title{
Liquidity Risk and Bank Performance: An Empirical Test for Tunisian Banks
}

\author{
Abdelaziz Hakimi (Corresponding author) \\ University of Jendouba, Faculty of Law \\ Economics and Management of Jendouba, Tunisia \\ Tel: 216-9708-9263Ｅ-mail: abdelazizhakimi@yahoo.fr
}

\author{
Khemais Zaghdoudi \\ University of Jendouba, Faculty of Law \\ Economics and Management of Jendouba, Tunisia
}

Tel: 216-9855-3863Ｅ-mail: k.zaghdoudi@yahoo.fr

$\begin{array}{ll}\text { Received: December 30, } 2016 & \text { Accepted: January 23, } 2017 \\ \text { doi:10.5296/ber.v7i1.10524 } & \text { URL: https://doi.org/10.5296/ber.v7i1.10524 }\end{array}$

\begin{abstract}
An important part of banking literature was interested in the relationship between credit risk and bank performance. However, only few studies investigated the association between liquidity risk and bank performance. The aim of this paper is to study the effect of liquidity risk on the Tunisian bank performance. To this end, we used a sample of 10 Tunisian banks over the period 1990-2013. By applying panel data method, precisely random effect regression, results show that liquidity risk decreases significantly Tunisian bank performance. Also, findings indicate that international financial crisis and inflation act negatively and significantly on bank performance.
\end{abstract}

Keywords: Liquidity risk, Bank performance, Tunisian banks, Panel data analysis

JEL Classification: G200, G210, G280

\section{Introduction}

Banks are distinguished from other financial institutions by the diversity of offered products and services. The assessment of bank performance is considered as an essential and necessary mechanism for the survival of these firms. Also, the soundness of a banking system is a 
crucial pillar for economic development. Hence, banks are the most involved financial institutions in the financing of the economy.

With reference to the classic functions, banking activities are based on liquidity. Hence, liquidity is the first product/service of each banking establishment. Taking into account the significant role of liquidity in the banking activities, there was an important attention granted to the liquidity risk. This risk threatens bank stability and leads to bank fragilities and failures.

Liquidity risk is defined as a situation when a bank can't meet all the request of depositors either totally or partially for a given period (Jenkinson, 2008). Also, it can be defined as the inability of a bank to meet short term financial demands. Liquidity risk can affect not only bank performance but also bank reputation. The insufficient liquidity causes erosion in depositor's confidence which leads to an opportunity cost.

Literature based on the relationship between liquidity and bank performance is ambiguous. Several studies reported that liquidity affects positively bank performance (Bourke, 1989), Kosmidou and al. (2005), Olagunju and al. (2012)). However, other studies defended the opposite thesis. They concluded that liquidity exerts a negative effect on bank performance under the misallocation of resources. Banks with high level of liquidity accept to finance risky projects with a high return but with a weak probability of success.

An important part of banking literature was interested in the determinant and consequences of credit risk. However, there were only few studies that investigated the relationship between liquidity risk and bank performance (Claeys and Vander Vennet, 2008; García-Herrero and al., 2009, Trujillo-Ponce, 2013). In our best knowledge, there were few papers that studied this relation for the Tunisian context. Banking sector is considered as the most involved sector in the financing of the Tunisian economy since the market finance is not well developed. In 2016, the Tunisian stock market covered only 79 listed firms and many of them are financial institutions. Liquidity is considered as a vital pillar in banking activities. For this reason, it's important to study the link between liquidity risk and bank performance especially in an indebted economy.

The objective of this paper is to investigate the relation between liquidity risk and Tunisian bank performance. To achieve this goal, we used a sample of 10 Tunisian banks over the period 1990-2015. By applying panel data analysis, precisely the random effect model, results show that liquidity risk decreases significantly the bank performance. Also, findings indicate that international financial crisis and inflation act negatively and significantly on bank performance.

The remainder of this paper is articulated as follows. Section 2 gives recent and brief literature review. In the section 3, we present an overview of liquidity risk and bank performance in Tunisia. Empirical analysis is presented in section 4. We conclude in section 5. 


\section{Literature Review}

Banks are the most important financial institutions that are involved in the financing of the economy. The investment banks are based on liquidity potential. Insufficient capital can limit the basic banking function based on collected deposits and granted credits. Even banks are face to a potential entrepreneur; they may refuse financing this agent when they feel that liquidity is not sufficient. It results in an opportunity loss for the banks (Diamond and Rajan (2001)). Hence, liquidity is considered as the main pillar that affects banks' performance and survival. Literature based on the relationship on this topic provided two groups. The first one studied the relation between liquidity and bank performance. The second one investigated the association between liquidity risk and bank profitability.

There were several studies that analyzed the effect of liquidity and/or liquidity risk on bank performance. Following the liquidity risk issues from the 2007 financial crisis, Cuong Ly (2015) investigated the association between liquidity risk and the performance of European banks. The sample used in this study is composed of a panel of EU27 observed during 2001-2011. The major findings of this research confirm a negative relationship between liquidity risk and bank performance. Another study that focused on the European context was done by Cucinelli (2013). In this study, the author studied the relationship between liquidity risk and probability of default. Using a sample of 575 listed and non-listed banks and based on the OLS regression, results indicate that there is no significant association between liquidity and probability of default in the long term.

Mamatzakis and Bermpei (2014) examined the main factors that explain the bank performance in the G7 and the Switzerland. The sample is composed of 97 banks. Results of panel data analysis show that liquidity impacts negatively bank performance. However, bank stability proxied by the Z-Score exerts a positive effect.

John and Olusegun (2015) studied the impact of liquidity on the Nigerian bank performance. They used a sample of 13 banks during the period 2004-2012. Results of GMM regression provide a positive relationship between liquidity and bank performance. They reported that banks should improve their liquidity to be more efficient. Marozva (2015) used a sample of South African banks over the period 1998-2014 to analyze the relation between liquidity risk and bank performance. In this study, bank performance is proxied by the net interest margin. Results of the Autoregressive Distributed Lag (ARDL)-bound approach reveal a negative and significant association between liquidity risk and bank performance. Curtis Lartey and al. (2013) analyzed the relation between liquidity and profitability in Ghana. Using seven listed banks during the period 2005-2010, they found that there is a weak positive effect of liquidity on bank profitability.

The Iranian example was investigated by Tabari and al. (2013). They used a sample of commercial banks over the period 2003-2010 to study the effect of liquidity risk on bank performance. The main results indicate that, besides the negative effect of credit risk, liquidity risk deceases also the performance of Iranian banks. Based on 22 Pakistani banks observed over the period 2004-2009, Arif and al. (2012) aimed to empirically analyze the impact of liquidity risk on bank performance. Results show that bank performance is 
negatively and significantly correlated with the liquidity risk. In this study, liquidity gap and non-performing loans are considered as the two main factors that involved liquidity risk.

\section{An Overview on the Evolution of Liquidity Risk and Bank Performance in Tunisia}

In this section, we analyze the evolution of the liquidity risk per banks and per years. We give also a description of the annual evolution of net interest margin for Tunisian banks. Statistics in tables below are related to 10 Tunisian banks which are considered as the most dynamic ones in Tunisia in term of economy financing. Table 1 below gives names and characteristics (public or private) of the sample.

Table 1. Names and characteristics of the 10 Tunisian banks

\begin{tabular}{|l|l|l|l|}
\hline & Abbreviation & Full Name & Public or private \\
\hline 1 & AB & Amen Bank & Private \\
2 & ATB & Arab Tunisian Bank & Private \\
3 & ATTIJARI & Attijari Bank & private \\
4 & BIAT & International Arab Tunisian Bank & private \\
5 & BH & Housing Bank & public \\
6 & BNA & National Agricultural Bank & Public \\
7 & BT & Tunisian Bank & Private \\
8 & STB & Tunisian Company Bank & Public \\
9 & UBCI & Union Banks of Trade and Industry & Private \\
10 & UIB & International Union of Banks & Private \\
\hline
\end{tabular}

Source: Tunisian Central Bank and Tunisian Association of Banks and Financial Establishments

In the following descriptive development, liquidity risk is measured by the total credit to total deposit ratio. This measure was used in several studies. For example we can quote Fiordelisi and Mare, 2014; Rose and Hudgins, 2008, Trujillo-Ponce, 2013. An increase of this ratio indicates that banks are more exposed to liquidity risk since they grant more credit than collects deposit. This situation leads to an insufficient liquidity especially in a massive and unexpected withdrawal of depositors. Banks appear to be unable to respond integrally or partially to requests of withdrawal.

As for bank performance, we used the net interest margin measured by to the ratio of interest margin to total Assets. There are many previous studies that used return on assets (ROA) or return on equity (ROE) as measure of performance (Curak and al., 2012; Adusei, 2015). In this study, we used the net interest margin (NIM) since it reflects more performance especially for banks which are based on traditional activities like Tunisian banks. The share of interest income in Tunisian banks is about $75 \%$. It's for this reason that we used the NIM as measure of performance like several studies Ghos (2016), Doyran (2013) and Nguyen (2012).

Table 2 below presents average annual evolution of liquidity risk for 10 banks over the period 1990-2013. Statistics used in this table are collected from annual reports of each bank. 
Table 2. Annual evolution of liquidity risk over the period 1990-2013

\begin{tabular}{|l|r|r|r|r|r|r|r|r|r|r|r|r|}
\hline Years & $\mathbf{1 9 9 0}$ & $\mathbf{1 9 9 1}$ & $\mathbf{1 9 9 2}$ & $\mathbf{1 9 9 3}$ & $\mathbf{1 9 9 4}$ & $\mathbf{1 9 9 5}$ & $\mathbf{1 9 9 6}$ & $\mathbf{1 9 9 7}$ & $\mathbf{1 9 9 8}$ & $\mathbf{1 9 9 9}$ & $\mathbf{2 0 0 0}$ & $\mathbf{2 0 0 1}$ \\
\hline LIQR \% & 120 & 127 & 134 & 131 & 124 & 133 & 120 & 105 & 113 & 096 & 106 & 109 \\
\hline Years & $\mathbf{2 0 0 2}$ & $\mathbf{2 0 0 3}$ & $\mathbf{2 0 0 4}$ & $\mathbf{2 0 0 5}$ & $\mathbf{2 0 0 6}$ & $\mathbf{2 0 0 7}$ & $\mathbf{2 0 0 8}$ & $\mathbf{2 0 0 9}$ & $\mathbf{2 0 1 0}$ & $\mathbf{2 0 1 1}$ & $\mathbf{2 0 1 2}$ & $\mathbf{2 0 1 3}$ \\
\hline LIQR \% & 109 & 109 & 105 & 103 & 94 & 169 & 188 & 191 & 106 & 102 & 110 & 107 \\
\hline
\end{tabular}

Source: Authors from annual reports of banks

Table 2 above presents the annual evolution of the liquidity risk for Tunisian banks during the period 1990-2013. For the period 1990-1992, statistics show an upward trend of the liquidity risk which crossed from $120 \%$ in 1990 to reach $134 \%$ in 1992. This risk registered a decrease during the period 1993-1994. It was $131 \%$ in 1993 and became $124 \%$ in 1994. Also, the same trend was registered during the period 1995-1997. During these two years, there was a decrease of the liquidity risk. It was $133 \%$ in 1995 and recorded $105 \%$ in 1997 . The liquidity risk continued to record an up down trend during the following years. It reached the weakest value of $96 \%$ in 1999 and $94 \%$ in 2006. During these two years, the total credits were lower than the total deposits.

However, from 2007 to 2009, the liquidity risk recorded the highest values respectively with $169 \%$ and $191 \%$. The increase of liquidity risk during this period is explained by the financial crisis which began at the end of 2007 and the beginning of 2008. During these two years, customers did not have trust in the bank solidity and feared banking failure. Hence, there was a decrease in the amount of deposits which led to an increase of the liquidity risk since it is measured by the total credits to the total deposits. For the rest of the period 2010-2013, the liquidity risk recorded stable values. During that period, we noticed that the total credits were almost equal to the total deposits. Hence, Tunisian banks registered a level of liquidity risk between 106\% in 2010 and $107 \%$ in 2013.

After analyzing the annual evolution of the liquidity risk, we aim in the following section to examine the evolution of this risk per banks.

Table 3 below indicates the evolution of the liquidity risk per bank. Data used in this table are related to the same sample, 10 banks over the period 1990-2013. In this table we calculate annual average value of liquidity risk for each bank. These statistics help us to detect on average the most exposed bank to liquidity risk.

Table 3. Average evolution of liquidity risk per bank during the period 1990-2013

\begin{tabular}{|c|c|c|c|c|c|c|c|c|c|c|}
\hline Banks & BNA & STB & BT & ATTIJARI & UIB & UBCI & AB & BIAT & ATB & BH \\
\hline LIQR\% & 154.2 & 120.7 & 120.4 & 116.0 & 115.1 & 129.1 & 113.6 & 103.6 & 96.7 & 143.5 \\
\hline
\end{tabular}

Source: Authors from annual reports of banks

This table shows that the BNA bank is the most exposed to liquidity risk with an average level of 154.2. This bank is followed by the BH bank which records a level of $143.5 \%$. In the third place, we find the UBCI bank with a risk rate of $129.1 \%$. The third public bank standed in the fourth place and registered a liquidity risk about $120.7 \%$. The weakest level of liquidity 
risk is recorded by the ATB bank with a level of $96.7 \%$.

From these statistics, we can conclude that the three public banks are more exposed to the liquidity risk more than private banks. Hence, state-owned banks are more involved in the financing of the economic activities. Consequently, these banks grant important amount of credits compared to the level of received deposits. In this case, there is an increase of the level of liquidity risk for these banks. Also, we can interpret the weak level of liquidity risk recorded by private banks as follows; first the credit policies for these banks are more rigid and not flexible. Second, the decision of credit is controlled by foreign decision especially in the case of merger and acquisition. Finally, private banks are not considered really as involved parties in the financing of the economies as public banks.

In the following paragraph, we give in Table 4 a descriptive evolution of net interest margin for Tunisian banks. First, we present the annual evolution of the bank performance proxied by the net interest margin (NIM). Second, we examine the evolution of the NIM per banks.

Table 4. Annual Evolution of the Net Interest Margin (NIM)

\begin{tabular}{|l|c|c|c|c|c|c|c|c|c|c|c|c|}
\hline Years & 1990 & $\mathbf{1 9 9 1}$ & $\mathbf{1 9 9 2}$ & $\mathbf{1 9 9 3}$ & $\mathbf{1 9 9 4}$ & $\mathbf{1 9 9 5}$ & $\mathbf{1 9 9 6}$ & $\mathbf{1 9 9 7}$ & $\mathbf{1 9 9 8}$ & $\mathbf{1 9 9 9}$ & $\mathbf{2 0 0 0}$ & $\mathbf{2 0 0 1}$ \\
\hline NIM & 2.5 & 2.3 & 2.3 & 2.6 & 3.2 & 3.4 & 3.7 & 3.6 & 3.6 & 4.1 & 4.0 & 3.9 \\
\hline Years & $\mathbf{2 0 0 2}$ & $\mathbf{2 0 0 3}$ & $\mathbf{2 0 0 4}$ & $\mathbf{2 0 0 5}$ & $\mathbf{2 0 0 6}$ & $\mathbf{2 0 0 7}$ & $\mathbf{2 0 0 8}$ & $\mathbf{2 0 0 9}$ & $\mathbf{2 0 1 0}$ & $\mathbf{2 0 1 1}$ & $\mathbf{2 0 1 2}$ & $\mathbf{2 0 1 3}$ \\
\hline NIM & 3.8 & 3.5 & 3.3 & 2.2 & 2.2 & 2.6 & 2.3 & 1.7 & 2.4 & 2.3 & 2.3 & 0.7 \\
\hline
\end{tabular}

Source: Authors from annual reports of banks

Table 4 above presents annual evolution of the NIM for Tunisian banks. Over the period 1990-1992, it was registered a decrease of the NIM which crossed from $2.5 \%$ to reach $2.3 \%$ in 1992. However, Table 4 shows that there was an increase of the bank performance during the period 1993-1996. The NIM was $2.6 \%$ in 1993 and became $3.7 \%$ in 1996. The highest level of NIM was recorded in the period of 1999-2000. During these two years, the NIM was respectively $4.1 \%$ and $4 \%$. In contrary, the weakest value was registered in 2009 with a value of $1.7 \%$. This level is considered as the consequences of the financial crisis which threatened bank stability. In this period, it was registered a decline of all principal banking indicators and banking activities. From 2010, there was an increase of the NIM which reached $2.4 \%$. However, the bank performance declined again to record the weakest value during the period of study with a level of $0.7 \%$ in 2013 .

In the following analysis, we will evaluate the average net interest margin recorded by each bank. This evolution is related to the period 1990-2013.

Table 5. Average evolution of Net Interest Margin per bank during the period 1990-2013

\begin{tabular}{|c|c|c|c|c|c|c|c|c|c|c|}
\hline Banks & BNA & STB & BT & ATTIJARI & UIB & UBCI & AB & BIAT & ATB & BH \\
\hline MIN\% & 2.4 & 2.0 & 3.5 & 3.3 & 2.5 & 4.0 & 2.6 & 3.3 & 2.3 & 2.7 \\
\hline
\end{tabular}

Source: Authors from annual reports of banks

From Table 5 above, we acknowledge that private banks are the most efficient with regard to the NIM. Firstly, we find that the UBCI bank with an average NIM of 4\%. Secondly, the BT 


\section{$\triangle 1$ Macrothink}

Business and Economic Research

ISSN 2162-4860

2017, Vol. 7, No. 1

bank which registered a level of 3.5\%. Attijari Bank comes in the third place with a level of performance of $3.3 \%$. The weakest level of performance is recorded by the state-owned banks. The STB bank is considered as the least efficient with a level of NIM only of $2 \%$. This bank is followed by the ATB and the BNA bank with respectively NIM of $2.3 \%$ and $2.4 \%$.

From these descriptive statistics related to liquidity risk and bank performance, we found that state-owned banks are the most exposed to liquidity risk and the least efficient. Hence, we can conclude that the highest liquidity risk is associated with the weakest level of performance.

\section{Empirical Analysis}

\subsection{Data and Methodology}

To test the effect of the liquidity risk on the Tunisian banking performance, we used a sample of ten (10) Tunisian banks over the period of 1990-2013. Accounting and financial data are collected from annual reports of each bank during the same period of study. For the empirical methodology, we perform the panel data analysis based on the random effect. Based on the individual (10 banks) and the temporal (1990-2013) characteristics of our data, the panel data method seemed to be the most appropriate.

\subsection{Model Specification and Variable Definition}

The econometric model used in this study combines some banking characteristics such as size, credit risk, capital adequacy, liquidity risk and index of concentration of Hirshmen Herfindahl (IHH). Besides banking characteristics, we added some macroeconomic variables to this model which can affect bank performance. We can quote the GDP growth and the inflation rate. The econometric model can be written as follows:

$$
\begin{gathered}
\operatorname{NIM}_{i, t}=\beta_{0}+\beta_{1} \operatorname{SIZE}_{i, t}+\beta_{2} \operatorname{CRDR}_{i, t}+\beta_{3} C A P_{i, t}+\beta_{4} L I Q R_{i, t}+\beta_{5} I H H_{i, t}+\beta_{6} \operatorname{CRISIS~}_{i, t}+ \\
\beta_{7} \operatorname{GDPG}_{i, t}+\beta_{8} I N F_{i, t}+£_{i, t}
\end{gathered}
$$

Table 6 below gives definition and measurement of each variable used in this study.

Table 6. Definition and measurement of variables

\begin{tabular}{|l|l|l|}
\hline Variables & \multicolumn{1}{|c|}{ Definition } & \multicolumn{1}{c|}{ Measurement } \\
\hline NIM & Bank performance & Measured by the ratio of interest margin to total Assets \\
\hline LIQR & Liquidity risk & Measured by the ratio of total credit to total deposit. \\
\hline CRDR & Credit risk & Measured by the total credit to total assets. \\
\hline CAP & Capital adequacy ratio & Measured by the ratio of total equity to total assets \\
\hline SIZE & Bank size & Measured by the Naperien logarithm of total assets \\
\hline IHH & Hirshmen Herfindahl index & Measured by the squared sum of market share of total assets. \\
\hline CRISIS & International financial crisis & Dummy variable which takes 0 before 2008 and 1 otherwise \\
\hline GDP & Gross domestic product & Measured by Growth rate of Gross domestic product \\
\hline INF & Inflation rate & Measured by Customer index price \\
\hline
\end{tabular}




\subsection{Results and Interpretation}

In this section, we present first descriptive statistics and correlation matrix. Second, we display and interpret results of our model.

\subsubsection{Descriptive Statistics and Correlation Matrix}

Table 7 presents descriptive statistics for all variables used in this study. We have information about each variable such as average value, standard deviation, minimum and maximum values.

Table 7. Descriptive statistics

\begin{tabular}{|l|c|c|c|c|c|}
\hline Variable & Obs & Mean & Std. Dev. & Min & Max \\
\hline NIM & 240 & 0.028 & 0.012 & -0.030 & 0.059 \\
\hline LIQR & 240 & 1.198 & 0.377 & 0.551 & 2.597 \\
\hline RCDR & 240 & 0.718 & 0.142 & 0.300 & 1.501 \\
\hline SIZE & 240 & 14.779 & 0.623 & 13.475 & 16.169 \\
\hline CAP & 240 & 0.081 & 0.037 & -0.016 & 0.249 \\
\hline CRISIS & 240 & 0.308 & 0.462 & 0 & 1 \\
\hline IHH & 240 & 0.111 & 0.009 & 0.088 & 0.123 \\
\hline GDPG & 240 & 0.040 & 0.022 & -0.023 & 0.079 \\
\hline INF & 240 & 0.042 & 0.015 & 0.020 & 0.082 \\
\hline
\end{tabular}

Table 7 above indicates that average NIM is $2.8 \%$ with a maximum of $5.9 \%$ and a minimum value of $-3 \%$. During the period 1990-2013, the liquidity risk (LIQR) recorded a mean value of $119.8 \%$ and a maximum value of $259.7 \%$. The mean value of credit risk (CRDR) was about $71.8 \%$ with a maximum value of $150.1 \%$ and a minimum value of $30 \%$.

The average level of the capital adequacy ratio is about $8.1 \%$. On average we can conclude that Tunisian banks are moderately capitalized. However, we find that the minimum value of CAP is $-1.6 \%$. It indicates that there are some banks which are poorly capitalized. For the index of concentration $\mathrm{IHH}$, it registered a level of $11.1 \%$ with maximum and minimum values respectively of $12.3 \%$ and $8.8 \%$.

As for the macroeconomic variable, the GDPG recorded an average of $4 \%$ with a maximum value of $7.9 \%$ and a minimum of $-2.3 \%$. The second variable is the inflation rate. The average value of this variable is $4.2 \%$ and the maximum level is $8.2 \%$.

Table 8 gives information about possible correlation between independent variables. It informs about the nature of correlation whether it is negative or positive and the level of correlation whether it is high or weak. 
Table 8. Correlation Matrix

\begin{tabular}{|l|c|c|c|c|c|c|c|c|c|}
\hline & NIM & LIQR & RCDR & SIZE & CAP & CRISIS & IHH & GDPG & INF \\
\hline NIM & 1.0000 & & & & & & & & \\
\hline LIQR & -0.2091 & 1.0000 & & & & & & & \\
\hline RCDR & -0.1042 & 0.2129 & 1.0000 & & & & & & \\
\hline SIZE & -0.3238 & -0.1709 & 0.1625 & 1.0000 & & & & & \\
\hline CAP & 0.1385 & 0.1907 & 0.3330 & -0.1103 & 1.0000 & & & & \\
\hline CRISIS & -0.4305 & 0.1119 & 0.4762 & 0.4858 & 0.0758 & 1.0000 & & & \\
\hline IHH & 0.2429 & 0.2482 & -0.4506 & -0.4687 & -0.1172 & -0.6504 & 1.0000 & & \\
\hline GDPG & 0.1793 & 0.0878 & -0.2915 & -0.3541 & -0.0397 & -0.5379 & 0.4732 & 1.0000 & \\
\hline INF & -0.3379 & 0.1095 & -0.0186 & 0.0915 & -0.2768 & 0.1923 & 0.1240 & 0.0529 & 1.0000 \\
\hline
\end{tabular}

From Table 8, we conclude that liquidity risk, credit risk, size, crisis and inflation rate are negatively correlated with the dependent variable. However, there is a positive association between capital adequacy ratio, index of concentration, growth of gross domestic product and bank performance. Also, Table 8 indicates that all coefficient of correlation between variables are very weak. The highest correlation $(44.8 \%)$ is between GDPG and IHH. This leads to confirm the absence of the multicolinearity problem.

\subsubsection{Findings}

Table 9 below summarizes the main findings of our study. The Hausman test value is 2.710 with p-value of $91.10 \%$ which is greater than $5 \%$. Hence the appropriate model is the random effect model.

Table 9. Results of Random effect regression

\begin{tabular}{|l|c|c|c|c|}
\hline Nim & Coef. & Std. Err. & $\mathrm{Z}$ & $\mathrm{P}>\mathrm{Z}$ \\
\hline LIQR & -0.009 & 0.002 & -4.82 & $0.000^{* * *}$ \\
\hline RCDR & 0.007 & 0.005 & 1.26 & 0.206 \\
\hline SIZE & -0.001 & 0.001 & -0.60 & 0.550 \\
\hline CAP & 0.011 & 0.018 & 0.63 & 0.529 \\
\hline CRISIS & -0.006 & 0.002 & -2.85 & $0.004^{* * *}$ \\
\hline IHH & 0.288 & 0.094 & 3.05 & $0.002^{* * *}$ \\
\hline GDPG & 0.000 & 0.000 & 0.11 & 0.914 \\
\hline INF & -0.002 & 0.000 & -5.52 & $0.000^{* * *}$ \\
\hline cons & 0.023 & 0.023 & 1.00 & 0.317 \\
\hline Hausman test & 4.25 & & \\
\hline prob chi 2 & & 0.834 & & \\
\hline Wald chi 2 & & 157.37 & & \\
\hline prob chi 2 & & 0.000 & & \\
\hline N of Obs. & & 240 & & \\
\hline
\end{tabular}

$* * *$, denotes level of significance at $1 \%$

Table 9 above shows results of random effect regression. From this table, we note that LIQR, 


\section{MInstitute ${ }_{\text {Mnk }}^{\text {Macrothink }}$}

Business and Economic Research

ISSN 2162-4860

2017, Vol. 7, No. 1

CRISIS, HHI and INF exert a significant effect. However, the effect of the other variables is not significant.

The liquidity risk (LIQR) is negatively and significantly correlated with bank performance. An increase in the liquidty risk is associated with a decrease of performance. Traditional bank activities are based on liquidity. Banks with insufficient liquidity may undergo a decline of income derived from loans activity. Consequently, the interest revenues decreased which leads to a decrease in the interest margin and bank performance. Furthermore, the insufficient liquidity can reduce bank reputation and customer trust in case of non-response to a withdrawal request.

The Hirshmen Herfindahl index acts positively and significantly at the level of $1 \%$ on the net interest margin. In this study, banking concentration improves the performance of Tunisian banks. A concentrated banking system provides more stability (Boyd, and al., 2005). On the contrary, in a competitive banking system, there is an increase of the risk taking behavior. Banks can accept to finance risky projects with high expected returns but with a low probability of success. These speculative and risk-taking behaviors reduce bank performance (Beck and al. 2006)).

The inflation (INF) variable acts negatively and significantly at the level of $1 \%$ on the net interest margin (NIM). In other words, an increase in inflation rate leads to a reduction in banking performance. High inflation can distort bank financing decisions. This flowed decision is likely to reduce future banking income (Ben Naceur and Goaid (2008)).

\section{Conclusion}

Banking activities are based on liquidity; hence this latter seems to be necessary for bank survival. Taking into account the significant role of liquidity in banking activities, there was an important attention granted to liquidity risk.

The aim of this paper is to investigate the effect of liquidity risk on bank performance. To this end, we used a sample of 10 Tunisian banks during the period 1990-2013. The econometric method served in this study is panel data analysis precisely the random effect model. Empirical results show that liquidity risk decreases significantly bank performance. Also, findings indicate that international financial crisis and inflation act negatively and significantly on bank performance. However, the effect of the other bank specifics such as credit risk, size and capital adequacy ratio are not significant.

These results have an important policy implications. Government, Banks and policy makers should pay attention to liquidity risk since it decreases significantly bank performance. In this study, the most disruptive of bank performance is liquidity risk. So, banks are invited to well manage this risk by reinforcing their own resources since depositors could at any time and under an unexpected reason, withdraw their capital to seek investment in new activities with higher returns. Regarding inflation, Tunisian government should stabilize macroeconomic environment to attract depositors and investors. An important level of trust towards banks leads to cumulate more capital which can be transformed to credit and be canalized in financing the economy. 
Concerning the crisis, it also affected the performance of banks through its impact namely on the behavior of depositors, who lose the desire to save, or demand high interest rates that can erode banking income.

\section{References}

Adusei, M. (215). The impact of bank size and funding risk on bank stability, Cogent Economics \& Finance, 3, 1-19. https://doi.org/10.1080/23322039.2015.1111489.

Arif, A., \& Nauman, A. (2012). Liquidity risk and performance of banking system, Journal of Financial Regulation and Compliance 20(2), 182-195.

https://doi.org/10.1108/13581981211218342

Beck, T., Demirgüç-Kunt, A., \& Levine, R. (2006a). Bank concentration, competition, and crises: First results. Journal of Banking and Finance, 30, 1581-1603.

https://doi.org/10.1016/j.jbankfin.2005.05.010

Ben Naceur, S., \& Goaied, M. (2008). The Determinants of Commercial Bank Interest Margin and Profitability: Evidence from Tunisia, Frontiers in Finance and Economics, 5(1), 106-130.

Bourke, P. (1989). Concentration and other determinants of bank profitability in Europe. North America and Australia, Journal of Banking and Finance, 13, 65-79.

https://doi.org/10.1016/0378-4266(89)90020-4

Boyd, J. H., \& De Nicoló, G. (2005). The theory of bank risk-taking and competition revisited. Journal of Finance, 60, 1329-1343. https://doi.org/10.1111/j.1540-6261.2005.00763.x

Claeys, S., \& Vander Vennet, R. (2008). Determinants of bank interest margins in Central and Eastern Europe: a comparison with the West, Economic Systems, 32, 197-216.

https://doi.org/10.1016/j.ecosys.2007.04.001

Cucinelli. D. (2013). The relationship between liquidity risk and probability of default: evidence from the Euro Area. Risk governance \& control: financial markets \& institutions, 3(1), 42-50. https://doi.org/10.22495/rgcv3i1art5

Cuong, Ly. K. (2015). Liquidity Risk, Regulation and Bank Performance: Evidence from European Banks. Global Economy and Finance Journal, 8(1), 11-33.

https://doi.org/10.21102/gefj.2015.03.81.02

Curak, M., Poposki. K., \& Pepur, S. (2012). Profitability Determinants of the Macedonian Banking Sector in Changign Environment, Procedia Social and Behavioral Sciences, 44, 406-416. https://doi.org/10.1016/j.sbspro.2012.05.045

Doyran, M. A. (2013), Net interest margins and firm performance in developing countries, Management Research Review, 36(7), 720-740. https://doi.org/10.1108/MRR-05-2012-0100

Fiordelisi, F., \& Mare, D. S., (2014). Competition and financial stability in European cooperative banks. Journal of International Money and Finance, 45, 1-16.

https://doi.org/10.1016/j.jimonfin.2014.02.008 


\section{Al Macrothink}

Business and Economic Research ISSN 2162-4860 2017, Vol. 7, No. 1

García-Herrero, A., Gavilá, S., \& Santabárbara, D. (2009). What explains the low profitability of Chinese banks? Journal of Banking and Finance, 33, 2080-2092.

https://doi.org/10.1016/j.jbankfin.2009.05.005

Ghos. A, (2016). Banking sector globalization and bank performance: A comparative analysis of low income countries with emerging markets and advanced economies. Review of Development Finance, 6, 58-70. https://doi.org/10.1016/j.rdf.2016.05.003

Jenkinson, N. (2008). Strengthening regimes for controlling liquidity risk, Euro Money, in Conference on Liquidity and Funding Risk Management, Available from Internet: https://www.bis.org/review/r080425f.pdf.

Kosmidou, K., Tanna, S., \& Pasiouras, F. (2005). Determinants of profitability of domestic UK commercial banks: Panel evidence from the period 1995-2002. In Money Macro and Finance (MMF) Research Group Conference (Vol. 45).

Lartey, V. C., Antwi, S., \& Boadi, E. K. (2013). The Relationship between Liquidity and Profitability of Listed Banks in Ghana. International Journal of Business and Social Science, 4(3), 48-56.

Mamatzakis, E., \& Bermpei, T. (2014). What drives investment bank performance? The role of risk, liquidity and fees prior to and during the crisis, International Review of Financial Analysis, 35, 102-117. https://doi.org/10.1016/j.irfa.2014.07.012

Marozva, G. (2015). Liquidity and Bank Performance. International Business \& Economics Research Journal, 14(3), 453-462. https://doi.org/10.19030/iber.v14i3.9218

Nguyen, J. (2012). The relationship between net interest margin and noninterest income using a system estimation approach. Journal of Banking and Finance, 36, 2429-2437.

https://doi.org/10.1016/j.jbankfin.2012.04.017

Olagunju, A., David, A. O., \& Samuel, O. (2012). Liquidity Management and Commercial Banks' Profitability in Nigeria. Research Journal of Finance and Accounting, 2(7-8), 24-38.

Rose, P. E., \& Hudgins, S. C. (2008). Bank management and Financial services (7th ed.). New York: McGraw Hill.

Tabari, N., Ahmadi, A., \& Emami, A. (2013). The Effect of Liquidity Risk on the Performance of Commercial Banks. International Research Journal of Applied and Basic Sciences, 4(6), 1624-1631.

Trujillo-Ponce, A. (2013). What determines the profitability of banks? Evidence from Spain. Accounting and Finance, 53, 561-586. https://doi.org/10.1111/j.1467-629X.2011.00466.x

\section{Copyright Disclaimer}

Copyright for this article is retained by the author(s), with first publication rights granted to the journal.

This is an open-access article distributed under the terms and conditions of the Creative Commons Attribution license (http://creativecommons.org/licenses/by/3.0/). 